\title{
Which mode and potency of electrocoagulation yields the Smallest Unobstructed Area of the Fallopian Tubes?
}

\section{Qual modo e potência produzem a menor área de não- obstrução nas tubas de Falópio?}

\author{
Marcelo Ivo Campagnolo ${ }^{1}$ Ricardo dos Reis ${ }^{1}$ Marcele Oliveira dos Santos ${ }^{1}$ Lúcia Maria Kliemann ${ }^{1}$ \\ Ricardo Francalacci Savaris ${ }^{1}$ \\ ${ }^{1}$ Department of Obstetrics and Gynecology, Universidade Federal do \\ Rio Grande do Sul, Porto Alegre, RS, Brazil \\ Rev Bras Ginecol Obstet 2018;40:332-337. \\ Address for correspondence Ricardo Francalacci Savaris, \\ Universidade Federal do Rio Grande do Sul, Rua Ramiro Barcelos 2350/ \\ 1124, 90035-903, Porto Alegre, RS, Brazil \\ (e-mail: rsavaris@hcpa.edu.br).
}

\begin{abstract}
Keywords

- tubal ligation

- fulguration

- occlusion

Objective To determine which mode and potency of electrocoagulation, using a modern electrosurgical generator, yields the smallest unobstructed area of the Fallopian tubes.

Methods In an experimental study, tubes from 48 hysterectomies or tubal ligation were evaluated. Tubes were randomly allocated to one of the following groups: group A) $25 \mathrm{~W} \times 5$ seconds $(n=17)$; group B) $30 \mathrm{~W} \times 5$ seconds $(n=17)$; group C) $35 \mathrm{~W} \times$ 5 seconds $(n=18)$, group D) $40 \mathrm{~W} \times 5$ seconds $(n=20)$; group E) $40 \mathrm{~W} \times 5$ seconds with visual inspection (blanch, swells, collapse) $(n=16)$; group F) $50 \mathrm{~W} \times 5$ seconds $(n=8)$. Bipolar electrocoagulation was performed in groups $A$ to $E$, and monopolar electrocoagulation was performed in group F. Coagulation mode was used in all groups. Digital photomicrography of the transversal histological sections of the isthmic segment of the Fallopian tube were taken, and the median percentage of unobstructed luminal area $\left(\mathrm{mm}^{2}\right)$ was measured with Image software (ImageJ, National Institutes of Health, Bethesda, MD, USA). The Kruskal-Wallis test or analysis of variance (ANOVA) was used for statistical analysis.

Results Ninety-six Fallopian tube sections were analyzed. The smallest median occluded area (\%; range) of the Fallopian tube was obtained in the group with $40 \mathrm{~W}$ with visual inspection (8.3\%; 0.9-40\%), followed by the groups $25 \mathrm{~W}(9.1 \% ; 0-35.9 \%)$, $40 \mathrm{~W}(14.2 ; 0.9-43.2 \%), 30 \mathrm{~W}(14.2 ; 0.9-49.7 \%), 35 \mathrm{~W}(15.1 ; 3-46.4 \%)$ and $50 \mathrm{~W}$ (38.2; 3.1-51\%). No statistically significant difference was found among groups ( $p=0.09$, Kruskal-Wallis test).
\end{abstract}

received

October 26, 2017

accepted

April 4, 2018

published online

May 29, 2018
DOI https://doi.org/

$10.1055 / \mathrm{s}-0038-1656718$.

ISSN 0100-7203.
Copyright $\odot 2018$ by Thieme Revinter

Publicações Ltda, Rio de Janeiro, Brazil
License terms

(c) $(1) \$$ 


\section{Resumo}

Palavras-chave

- ligadura tubária

- fulguração

- oclusão
Conclusion The smallest unobstructed area was obtained with power setting at $40 \mathrm{~W}$ with visual inspection using a modern electrosurgical generator. However, no statistically significant difference in the unobstructed area was observed among the groups using these different modes and potencies.

Objetivo Determinar em qual modo e potência, usando unidades geradoras modernas de eletrocoagulação, produz a menor área de não-obstrução das tubas de Falópio. Métodos Num estudo experimental, tubas uterinas derivadas de 48 histerectomias ou ligadura tubária foram avaliadas. As tubas foram alocadas aleatoriamente para um dos seguintes grupos: grupo A) $25 \mathrm{~W} \times 5$ segundos $(n=17)$; grupo B) $30 \mathrm{~W} \times 5$ segundos ( $n=17$ ); grupo C) $35 \mathrm{~W} \times 5$ segundos ( $n=18$ ), grupo D) $40 \mathrm{~W}, 5$ segundos $(n=20)$; grupo E) $40 \mathrm{~W} \times 5$ segundos inspeção visual (branqueia, incha e colapsa) $(n=16)$; grupo F) $50 \mathrm{~W} \times 5$ segundos $(n=8)$. A eletrocoagulação bipolar foi usada nos grupos de $\mathrm{A}$ a $\mathrm{E}$, e a eletrocoagulação monopolar, no grupo $\mathrm{F}$. O modo de coagulação foi utilizado em todos os grupos. Cortes histológicos transversais do segmento ístmico das tubas de Falópio foram corados e fotografados digitalmente, e a percentagem da área luminal $\left(\mathrm{mm}^{2}\right)$ não-obstruída foi medida com o software ImageJ (ImageJ, National Institutes of Health, Bethesda, MD, USA). O teste de Kruskal-Wallis ou ANOVA foram usados para a análise estatística.

Resultados Noventa e seis cortes histológicos de tubas de Falópio foram analisados. A mediana da menor área não-obstruída (\%; amplitude) da tuba de Falópio foi obtida no grupo $40 \mathrm{~W}$ com inspeção visual $(8,3 \% ; 0,9-40 \%)$, seguido do grupo $25 \mathrm{~W}(9,1 \% ; 0$ $35,9 \%), 40 \mathrm{~W}(14,2 ; 0,9-43,2 \%), 30 \mathrm{~W}(14.2 ; 0,9-49,7 \%), 35 \mathrm{~W}(15,1 ; 3-46,4 \%)$ e $50 \mathrm{~W}$ $(38,2 ; 3.1-51 \%)$. Não houve diferença significativa entre os grupos $(p=0,09$, teste de Kruskal-Wallis).

Conclusão A menor área não-obstruída foi obtida com a potência de $40 \mathrm{~W}$ com inspeção visual usando um gerador moderno de eletrocirurgia. Contudo, nenhuma diferença significativa na área não-obstruída foi observada entre os grupos usando esses modos e potências.

\section{Introduction}

Tubal ligation is an effective form of permanent female contraception. In the world, it is the most commonly used method of permanent contraception selected by women aged between 15 and 49 who are married or in union. ${ }^{1}$ In the United States, it is the second most commonly used form of contraception. ${ }^{2}$ Among the different methods of tubal ligation, the monopolar electrocoagulation has the lowest long-term failure rate, ${ }^{3}$ but has been associated with thermal injury to the bowel and is rarely used. ${ }^{4}$ Laparoscopic bipolar coagulation is a safe technique according to the American College of Obstetricians and Gynecologists (ACOG) practice bulletin. ${ }^{4}$ The ACOG recommends that at least $3 \mathrm{~cm}$ of the isthmic portion of the Fallopian tube must be completely coagulated. ${ }^{4}$ According to Soderstrom et al, ${ }^{5}$ they were able to verify that with $35 \mathrm{~W}$ of potency, $100 \%$ of the tubes had a complete occlusion of the lumen, while with $25 \mathrm{~W}$, none of the tubes had a complete occlusion. Nonetheless, the $95 \%$ confidence interval ( $\mathrm{Cl}$ ) of the data derived from Soderstrom et $\mathrm{al}^{5}$ revealed a wide range in both groups: $100 \%$ (5 out of 5 : $95 \%$ CI 56.6-100) using bipolar coagulation at $35 \mathrm{~W}$, while zero cases had a total occluded area with $25 \mathrm{~W}$ ( 0 out of 5 : $95 \%$ CI 0-43).

The use of inline ammeter has been advocated when tubal ligation is performed, since visual inspection is not accurate to identify the complete fulguration of the Fallopian tube., The use of inline ammeter is not recommended or mentioned by the Brazilian Health Ministry ${ }^{7}$ or the Brazilian Federation of Gynecologists and Obstetricians (FEBRASGO, in the Portuguese acronym). ${ }^{8}$

Modern electrosurgical generators (solid-state electrosurgical generators) provide constant power output by measuring the output voltage and current and adjusting the drive signal to compensate for changes in the equivalent load impedance. ${ }^{9}$ Therefore, it is necessary to provide evidences that the current practice of tubal ligation without inline ammeter, using the bipolar mode in a modern electrosurgical generator, delivers enough energy to collapse the lumen of the Fallopian tube. The objective of this study is to determine which configuration and power setting of electrocoagulation, using a modern electrosurgical generator, yield the smallest unobstructed area of the Fallopian tubes. 


\section{Methods}

\section{Study Design and Setting}

This experimental study took place between April $1^{\text {st }} 2010$ and December $30^{\text {th }} 2011$, at Hospital Femina located in Porto Alegre, Rio Grande do Sul, Brazil.

\section{Fallopian Tubes}

The Fallopian tubes were obtained from consecutive women who were scheduled for tubal ligation or hysterectomy for benign conditions. Subjects were invited to participate in the study and gave their written consent. The inclusion criteria consisted in normal Fallopian tubes and age $\leq 50$ years-old. Those who had gynecologic cancer, hydrosalpinx, isthmic segment of the Fallopian tube $<3 \mathrm{~cm}$ and abnormal anatomy of the Fallopian tube were excluded. These surgeries were performed by one of the authors (Campagnolo M.I.), or by another surgeon previously instructed about the protocol.

\section{Randomization}

The randomization list was generated by an online program (www.randomization.com) using blocks of four. The randomized list was kept in sequenced sealed envelopes, which were opened at the beginning of the surgery.

\section{Intervention}

During the procedure, each tube was randomly allocated to one of the following groups: group A) $25 \mathrm{~W} \times 5$ seconds; group B) $30 \mathrm{~W} \times 5$ seconds; group C) $35 \mathrm{~W} \times 5$ seconds; group D) $40 \mathrm{~W} \times 5$ seconds; group E) $40 \mathrm{~W} \times 5$ seconds visual inspection (blanch, swells, collapse); group F) $50 \mathrm{~W}$ x $5 \mathrm{sec}-$ onds. All groups used the coagulation mode, because it is not possible to use the cutting mode in bipolar electrocoagulation. Bipolar electrocoagulation was applied in groups A to E, and monopolar electrocoagulation was performed in group $\mathrm{F}$.

Electrocoagulation was performed in the coagulation mode using the WEM Model SS-501S electrosurgical generator (WEM Equipamentos Eletrônicos Ltda, Ribeirão Preto, SP, Brazil) with the Edlo bipolar forceps Ref. 14.1048 (EDLO, Canoas, RS, Brazil), or the Rhosse monopolar forceps Ref. 12231 (Rhosse, Ribeirão Preto, SP, Brazil). Bipolar coagulation of the tubes was performed on an auxiliary table after the uterus was removed. Due to the characteristics of the monopolar system, electrocoagulation of the Fallopian tubes was performed before the removal of the uterus. Monopolar coagulation has been considered the most efficient method, as described in the literature, ${ }^{3}$ and was limited to eight samples.

Fulguration of the tubes was performed on 3 contiguous areas, at least $3 \mathrm{~cm}$ in length, as recommended in the literature. ${ }^{10}$

\section{Outcome/Data Sources/Measurements}

The mean occluded area of the Fallopian tube after fulguration in each group was the main outcome. This outcome was analyzed in terms of $\mathrm{mm}^{2}$ and percentage of the transversal section of the Fallopian tube that was unobstructed. The time to achieve the collapse of the Fallopian tube in group E was analyzed in seconds. To analyze these variables, the coagulated tubes were resected and fixed in a formaldehyde (10\%) solution and embedded in paraffin for histological analysis. The paraffin blocks were cut $4 \mu \mathrm{m}$ thick and stained with hematoxylin and eosin.

The data sources were obtained after microscopic analysis of four transversal sections taken from each block. The section with the highest thermal injury, according to Soderstrom et $a{ }^{5}{ }^{5}$ was chosen for digital photomicrography. Digital pictures were taken using an Olympus BX51 microscope (Olympus Optical Co., Tokyo, Japan) connected to a digital color camera/Q-Color 5 (Olympus, Waltham, MA 02453, USA). The images were obtained with a UPlanFI $4 \mathrm{X}$ objective lens (Olympus, Waltham, MA, USA) (resolution: $2.75 \mu \mathrm{m}$ ), at a size of $2,560 \times 1,920$ pixels (resolution: $1 \mathrm{~mm}=590$ pixels), under standard lighting conditions.

To reduce bias, each slide was coded, and the unobstructed area of the lumen was blindly analyzed for the outcomes (open luminal area in $\mathrm{mm}^{2}$ and percentage of area that was open in the lumen). These outcomes were analyzed with ImageJ software, v1.43j (ImageJ; National Institutes of Health, Bethesda, MD, USA). Briefly, a circle was drawn around the lumen of the Fallopian tube. The outside area was cleared, and the image was converted into 8 bits. The image was adjusted for a threshold, using a dark background. Next, the region of interest (ROI) manager was activated and saved in a file. From the ROI manager, the software calculated the total and relative open area of the section.

\section{Sample Size}

The sample size was calculated based on data previously published $^{5}$ and using the formula described in the literature for superiority trial for continuous outcome. ${ }^{11}$ The following parameters were used: an $\alpha$ error of 0.05 , power of 0.8 , median lumen occlusion (100\%) using bipolar coagulation at $35 \mathrm{~W}$, an expected reduction of the mean occluded area by $85 \%$ with lower potencies $(25 \mathrm{~W})$, and a standard deviation of 10 . The standard deviation value was obtained from a pilot study in tubes that used visual fulguration. These figures yielded a sample size of a minimum of eight cases in each group.

\section{Statistical Methods and Ethics}

GraphPad Prism version 6 for Macintosh (GraphPad Software, Inc., San Diego, CA, USA) was used for statistical analysis of the variables, using the Kruskal-Wallis test. Gaussian distribution of the data was verified by the D'Agostino \& Pearson omnibus normality test. Ethnicity was analyzed using descriptive statistics. This study was submitted and approved by the Research Ethics Committees of Hospital de Clínicas de Porto Alegre and Grupo Hospitalar Conceição, under the numbers 09-624 and 09-253, respectively.

\section{Results}

Fifty-nine women were invited to participate in the study, and 11 were excluded (6 had a short isthmic segment; 5 had abnormal anatomy of the Fallopian tube). Forty-eight women, that is, 96 Fallopian tubes were fulgurated; 88 were submitted to bipolar and 8 to monopolar coagulation. Four tubes were discarded after randomization for technical problems during 
Table 1 Baseline characteristics of the studied population

\begin{tabular}{|c|c|c|c|c|c|c|c|}
\hline \multirow[t]{2}{*}{ Parameter } & \multicolumn{6}{|c|}{ Group of fulguration settings } & \multirow[t]{2}{*}{$P^{\mathrm{i}}$} \\
\hline & $25 W^{a}$ & $30 \mathrm{w}^{\mathrm{b}}$ & $35 W^{c}$ & $40 W^{d}$ & $40 W v^{e}$ & $50 W^{f}$ & \\
\hline $\mathrm{Age}^{g}$ & $40.7(8)$ & $37.6(7.7)$ & $43.6(8.8)$ & $37.1(8.2)$ & $40.4(8.3)$ & $40(4)$ & 0.5 \\
\hline Gestations $^{g}$ & $3.2(1.5)$ & $2.9(1.5)$ & $2.8(1.2)$ & $3.3(0.9)$ & $2.8(1.2)$ & $1.5(1.7)$ & 0.3 \\
\hline Parity $^{9}$ & $3.2(1.5)$ & $2.8(1.6)$ & $2.5(1.3)$ & $3.1(1.3)$ & $2.6(1.1)$ & $1.5(1.7)$ & 0.4 \\
\hline \multicolumn{8}{|l|}{ Ethinicity $^{\mathrm{h}}$} \\
\hline Caucasian & 3 & 9 & 5 & 3 & 6 & 2 & \\
\hline Non-caucasian & 11 & 2 & 3 & 5 & 2 & 2 & \\
\hline \multicolumn{8}{|l|}{ Tubes from } \\
\hline Abd hysterec & 5 & 4 & 4 & 3 & 0 & 8 & \\
\hline Vag hysterec & 3 & 3 & 6 & 4 & 6 & 0 & \\
\hline BTL-Abdomen & 8 & 10 & 7 & 12 & 9 & 0 & \\
\hline BTL-Vaginal & 1 & 0 & 0 & 0 & 1 & 0 & \\
\hline $\mathrm{BSO}$ & 0 & 0 & 1 & 1 & 0 & 0 & \\
\hline Total $n$ of tubes & 17 & 17 & 17 & 18 & 15 & 8 & \\
\hline
\end{tabular}

Abbreviations: Abd hysterec., abdominal hysterectomy; BSO, bilateral salpingo-oophorectomy; BTL, bilateral tubal ligation; Vag hysterec., vaginal hysterectomy.

${ }^{a} 25 \mathrm{~W} \times 5$ seconds-bipolar;

b30 W $\times 5$ seconds-bipolar;

' $35 \mathrm{~W} \times 5$ seconds-bipolar;

d $40 \mathrm{~W} \times 5$ seconds-bipolar;

e $40 \mathrm{~W}$ visual inspection-bipolar;

$\mathrm{f}_{50 \mathrm{~W}} \times 5$ seconds-monopolar;

${ }^{9}$ numbers are given as means (standard deviation);

heach Fallopian tube of a patient was randomized to a different group;

'analysis of variance (ANOVA).

histopathology processing (one in the $35 \mathrm{~W}, 2$ in the $40 \mathrm{~W}$ and 1 in the $40 \mathrm{~W}$ visual). The characteristics of the groups are depicted in - Table 1.

The median [range] unobstructed area $\left(\mathrm{mm}^{2}\right)$ of each group was: $\mathrm{A}=0.13[0-3.96], \mathrm{B}=0.17[0.01-3.3], \mathrm{C}=0.33$ $[0.03-4.61], \quad \mathrm{D}=0.22[0-3.53], \mathrm{E}=0.27[0.01-.45]$ and $\mathrm{F}=0.94[0.08-2.67]$. No statistical significance was found $(p=0.3-$ Kruskal-Wallis test- - Fig. 1A). In contrast, the smallest median unobstructed area considering the percentage of the total area (\%) of the Fallopian tube was obtained in group $\mathrm{E}$ ( $40 \mathrm{~W}$ visual inspection-8.3\%; range from $0.9-40 \%$ ), although no statistically significant difference was found among the groups $(p=0.09$, Kruskal-Wallis test-Fig. 1B). The mean (SD) time of coagulation for each grasp in group E was 3.8 (1) seconds. The largest median unobstructed area was obtained with the monopolar method with 38.2\% (range 3.1-51\%--Fig. 1B). Examples of tubal occlusion with different power settings are depicted in - Fig. 2.

\section{Discussion}

The new feature of modern electrosurgical generators, where constant electronic adjustments provide constant power through different tissue changes, leads us to investigate if total fulguration of the Fallopian tube, using different potencies and modes of fulguration settings presented herein, could be achieved without the use of an inline ammeter.
We were not able to find any statistical difference among groups. The bipolar mode, independently of the wattage used, yielded a median occluded area of $85 \%$ or more, while the $40 \mathrm{~W}$ with visual inspection provided around $92 \%$ of occlusion. Occlusion of the luminal area close to $0 \%(0-1 \%)$ was observed in one sample of the $25 \mathrm{~W}$ group $(0 \%)$, one in the $30 \mathrm{~W}(0.9 \%)$, one in the $40 \mathrm{~W}(0.7 \%)$ and one in the $40 \mathrm{~W}$ visual inspection (0.9\%). These findings may be explained by the high-peak bursts that desiccate the outer layers of the tube too quickly and prevents the deep penetration of the energy. This phenomenon may explain the smallest coagulation area (around 61\%) obtained with monopolar coagulation, which used 50W.

Based on our findings, it seems reasonable to follow the international recommendations to use an inline ammeter, which is incorporated with most bipolar generators in the US, to confirm total occlusion., ${ }^{5,12}$ This recommendation is based on a review of 2,267 procedures done before 1987, where failures on tubal ligation were observed. ${ }^{13}$ In 1989 , Soderstrom et al, ${ }^{5}$ using 5 tubes derived from hysterectomy, demonstrated that bipolar system using $35 \mathrm{~W}$ in the coagulation mode yielded complete coagulation of the Fallopian tube. Likewise, using 20 tubes, complete coagulation of the Fallopian tube was obtained with $25 \mathrm{~W}$ in the cutting mode. These results were based on an old Kepplinger and Valleylab generators. ${ }^{5}$

Modern electrosurgical generators have electronic adjustments, which provide constant power through different 

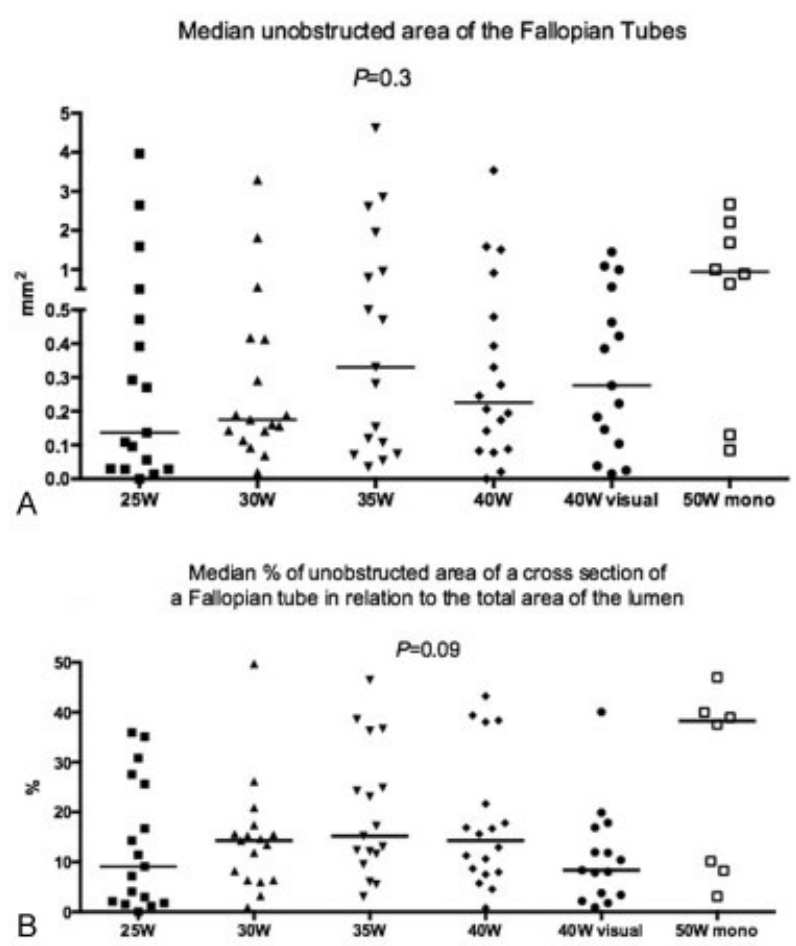

Fig. 1 Median area (A) and percentage of the total area (B) of a transversal section of the Fallopian tube that was unobstructed by different configurations and power settings (W). The bars represent the median value. The statistical analysis was performed using the Kruskal-Wallis test. The area was calculated using ImageJ software. Mono: monopolar fulguration. tissue changes, and can offer up to $40 \mathrm{~W}$. These new electrosurgical generators have a computer-controlled tissue feedback response system that senses tissue impedance and corrects the energy flow. ${ }^{14}$ In contrast, modern electrosurgical generators do not offer "pure cut" in the bipolar mode, thus the use of an inline ammeter seems to be necessary to indicate when the current through the Fallopian tube has ceased flow.

Unfortunately, an inline ammeter is not sold in Brazil, and the only orientation given by the Brazilian Health Ministry and other institutions, such as the Brazilian Federation of Gynecologists and Obstetricians (FEBRASGO, in the Portuguese acronym), is that the procedure should be performed with bipolar mode. ${ }^{7,8}$ This lack of details could be related to the report that bipolar coagulation system is highly effective for bilateral tubal ligation, if a segment of $\geq 3 \mathrm{~cm}$ is coagulated. ${ }^{13}$

The strengths of this study are the calculated sample size and the use of ImageJ software to quantify the unobstructed area of the Fallopian tube. Using an $\alpha$ error of 0.05 and data on unobstructed area $\left(\mathrm{mm}^{2}\right)$, post-hoc analysis revealed a power of $95.7 \%$ comparing groups $40 \mathrm{~W}$ visual inspection vs $50 \mathrm{~W}$ and $94.2 \%$ comparing $40 \mathrm{~W}$ vs $50 \mathrm{~W}$. Image J provides an unbiased quantification of the open area, and this approach and this approach is likely to be superior to visual inspection. ${ }^{15}$ Initially, we used the histological grading described by Soderstrom et $\mathrm{al}^{5}$ but the high inter- and intraobserver variation (data not shown) led us to use the ImageJ software, a widely used software for this and other purposes. ${ }^{16-19}$
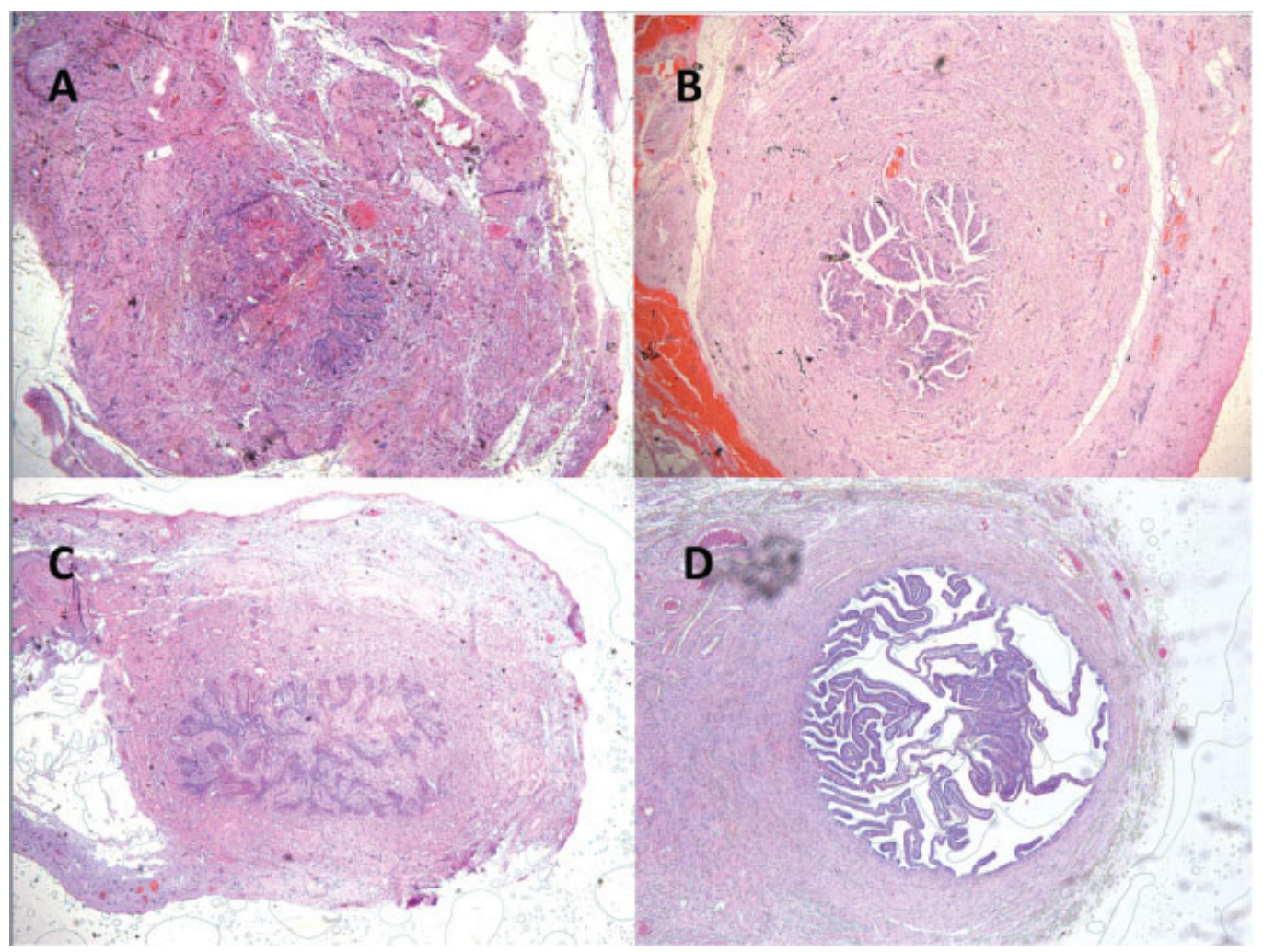

Fig. 2 Photomicrograph of representative sections stained with hematoxylin \& eosin. Total occlusion of the Fallopian tube using 25 W (A) and $40 \mathrm{~W}$ visual (C). Partial occlusion of the lumen of the Fallopian tube using $40 \mathrm{~W}$ (B); inadequate occlusion of the lumen of the Fallopian tube using monopolar fulguration at $50 \mathrm{~W}$ (D). Magnification was 200x. 
The main weakness of the study is the degree of thermal injury. The histological analysis was done after the electrocoagulation was performed. It has been shown that complete occlusion may take up to 8 weeks to occur. ${ }^{20}$ Therefore, our data may underestimate the real rate of the tubal occlusion. Another minor weakness is the lack of external validity. Just one electrosurgical generator was used, so no extrapolations can make to other models.

Although no significant difference was found among the groups, the mean occluded area was higher in the monopolar mode, and this was an unexpected finding. This study brings new data about the monopolar occlusion rate at $50 \mathrm{~W}$, which was thought to be the best method for tubal occlusion. Different settings for tubal fulguration, such as lower wattage and longer time, may be sought to reach the best occlusion rate without using an inline ammeter. A low-cost alternative for the Brazilian population may be the use of an ammeter plier in one of the cables of the bipolar.

\section{Conclusion}

In summary, the modern electrosurgical generator used herein yielded a similar degree of damage on the Fallopian tube independently of the configuration and power setting used, and none of these settings reached a mean occluded area of $100 \%$.

Conflicts of Interest

The authors have no conflicts of interest to disclose.

\section{Contributions}

Campagnolo M. I., Reis R., Santos M. O., Kliemann L. M. and Savaris R. F. contributed with project and interpretation of data, writing of the article, critical review of the intellectual content and final approval of the version to be published.

Acknowledgments

Fundo de Incentivo a Pesquisa e Eventos (FIPE, in the Portuguese acronym)-Hospital de Clínicas de Porto Alegre, Grant 09-624.

\section{References}

1 United Nations. Department of Economic and Social Affairs. Population Division. World Contraceptive Use 2010 (POP/DB/CP/ Rev2010). 2011. http://www.un.org/esa/population/publications/ wcu2010/WCP_2010/Data.html. Accessed October 22, 2017

2 Kavanaugh ML, Jerman J. Contraceptive method use in the United States: trends and characteristics between 2008, 2012 and 2014. Contraception 2018;97(01):14-21. Doi: 10.1016/j.contraception. 2017.10.003
3 Peterson HB, Xia Z, Hughes JM, Wilcox LS, Tylor LR, Trussell J. The risk of pregnancy after tubal sterilization: findings from the U.S. Collaborative Review of Sterilization. Am J Obstet Gynecol 1996; 174(04):1161-1168, discussion 1168-1170. Doi: 10.1016/S00029378(96)70658-0

4 American College of Obstetricians and Gynecologists. ACOG Practice bulletin no. 133: benefits and risks of sterilization. Obstet Gynecol 2013;121(2 Pt 1):392-404. Doi: 10.1097/01. AOG.0000426425.33845.b2

5 Soderstrom RM, Levy BS, Engel T. Reducing bipolar sterilization failures. Obstet Gynecol 1989;74(01):60-63

6 Canela CD, Bhimji SS. Tubal sterilization. In: StatPearls. Treasure Island (FL): StatPearls Publishing; 2017

7 Ministry of Health. Secretary of Health Policies. Technical Area of Women's Health. [Family Planning Assistance: Technical Manual]. Brasília, DF: Ministry of Health; 2002. http://bvsms.saude.gov.br/ bvs/publicacoes/0102assistencia2.pdf. Accessed October 22, 2017

8 Federação Brasileira das Associações de Ginecologia e Obstetrícia. Manual de Orientação Anticoncepção. São Paulo, SP: FEBRASGO; 2010

9 Pearce J. Electrosurgical Unit (ESU). In: Webster JG, ed. Encyclopedia of Medical Devices and Instrumentation. Vol. 3. Hoboken, NJ: John Wiley \& Sons; 2006:156-177

10 Textbook of laparoscopy. [Review of Book] Gynaecol Endosc 1996; $5: 257$

11 Julious SA. Sample sizes for clinical trials with normal data. Stat Med 2004;23(12):1921-1986. Doi: 10.1002/sim.1783

12 Hoffman BL, Schorge JO, Schaffer JI, et al. Minimally invasive surgery. In: Hoffman BL, Schorge JO, Schaffer JI, et al. Williams Gynecology. $2^{\text {nd }}$ ed. New York, NY: McGraw-Hill Global Education Holdings; 2012http://www.accessmedicine.com/content.aspx? $\mathrm{aID}=56719005$. Accessed October 22, 2017

13 Peterson HB, Xia Z, Wilcox LS, Tylor LR, Trussell J; U.S. Collaborative Review of Sterilization Working Group. Pregnancy after tubal sterilization with bipolar electrocoagulation. Obstet Gynecol 1999;94(02):163-167. Doi: 10.1016/S0029-7844(99)00316-6

14 Advincula AP, Wang K. The evolutionary state of electrosurgery: where are we now? Curr Opin Obstet Gynecol 2008;20(04): 353-358. Doi: 10.1097/GCO.0b013e3283073ab7

15 Fuhrich DG, Lessey BA, Savaris RF. Comparison of HSCORE assessment of endometrial beta3 integrin subunit expression with digital HSCORE using computerized image analysis (ImageJ). Anal Quant Cytopathol Histpathol 2013;35(04):210-216

16 Batchu K, Ebong A. The use of ImageJ software to correlate the percentage area of Ag crystallites to contact resistance in Si solar cells. In: Paper presented at HONET-ICT, 2016; October 2016; Nicosia, Cyprus

17 Baviskar SN. A quick \& automated method for measuring cell area using ImageJ. Am Biol Teach 2011;73:554-556. Doi: 10.1525/ abt.2011.73.9.9

18 Gallagher SR. Digital image processing and analysis with ImageJ. Curr Protoc Essent Lab Tech 2010;3:1-24

19 Broeke J, Perez JMM, Pascau J. Image Processing with ImageJ. $2^{\text {nd }}$ ed. Birmingham: Packt; 2015

20 Tucker RD, Benda JA, Mardan A, Engel T. The interaction of electrosurgical bipolar forceps and generators on an animal model of fallopian tube sterilization. Am J Obstet Gynecol 1991; 165(02):443-449. Doi: 10.1016/0002-9378(91)90114-7 